\title{
INTERNATIONALISMS, ANGLO-LATINISMS AND OTHER KINSHIP TIES BETWEEN ITALIAN AND ENGLISH
}

Keywords: internationalism, language contact, linguistic borrowing, Anglicism

\begin{abstract}
In the analysis of language contact and borrowing, the category of internationalism denotes lexical items that are formally and semantically similar across unrelated languages, mainly of neo-classical origin. Internationalisms are characteristically unmarked for a specific national provenance, like the pair En electricity / It elettricità. On the other hand, many similar examples, such as En romantic and It romantico, are the result of borrowings from English into Italian, a fact that can be established only on historical grounds, because the word itself does not reveal any trace of foreignness to the lay Italian speaker, being Italian a Latin-based language. In this paper, the lexical category of internationalism will be defined and set apart from other outcomes of language contact, like direct and indirect Anglicisms, Anglo-Latinisms, and other forms of linguistic kinship between these two, partly unrelated, European languages. Linguistic factors such as etymology, route of transmission, and non-linguistic ones such as historical events and motivation for borrowing (Wexler 1969) are used for this analysis, which will be applied to relevant examples of Italian vocabulary.
\end{abstract}

\section{Introduction}

In the history of language contact between Italian and English, the lexical categories of internationalisms and Anglo-Latinisms bear testimony to ancient roots common to these two languages. They signal "kinship ties" between English and the many Latin-based languages of Europe, since a strong classical and Romance component 
is genetically imprinted in their vocabularies. The Italian language developed from Latin, its "mother tongue", through the centuries (Tekavčić 1980). ${ }^{1}$ Also for English, despite its Germanic core, the Latin and Romance components have strongly fed into its historical genesis. ${ }^{2}$ Apart from the input already under way in the Middle Ages, English rapidly and massively expanded its vocabulary from the Renaissance, drawing on Latin and French (Carstairs-McCarthy 2002; Plag 2003; Hogg, Denison 2006; Minkova, Stockwell 2009). As a result, "the Modern English vocabulary is less Germanic than foreign, at least as far as the lexical types go" (Hogg, Denison 2006: 270). Latin and Greek were also the primary sources for the designation and categorization of specialized terminologies in $18^{\text {th }}$-century Europe, following the industrial revolution and scientific and technical progress in a many fields of human knowledge (Pulcini, Milani 2017).

Historically, therefore, English and Italian share a large stock of matching vocabulary: most items are "good friends", with similar form and meaning (e.g. En family, It famiglia from classical Lat familia 'household'), while some are "false friends", with similar forms but different meaning (e.g. En parent vs It parente, 'relative', where the Latinate sense 'father or mother' [Lat parens, -tes] was extended to other family members) (Pulcini 1997). When it comes to borrowing from the English language - a phenomenon which intensified from the $18^{\text {th }}$ century but increased exponentially from the second half of the $2 \mathrm{O}^{\text {th }}$ century in most European languages (Pulcini 2002, 2017) - we can distinguish between direct (adapted and unadapted) and indirect borrowings (calques and semantic loans) (Pulcini et al. 2012). While unadapted Anglicisms remain recognizably English (e.g. manager ${ }^{3}$ ), adapted ones are formally integrated into the receiving language system and their foreign identity may go unnoticed to non-expert Italian users (e.g. It sportivo 'sports adj.'); even more so in the case of calques (e.g. It banconota $<$ En banknote) and semantic loans (e.g. It realizzare < En realize 'understand'), when the meaning of the English source word is reproduced with an already existing Italian word. This formal similarity is particularly deceitful when the formal identity of the source word comes from a classical root, like the Italian adjective romantico (borrowed in 1824 from $17^{\text {th }}$ c. En romantic; from Lat romanticus), further discussed below. In these cases, only philologists and language experts may be aware of the English provenance

\footnotetext{
Apart from Latin and Greek, French is the language that mostly enriched the Italian lexicon from its origins in the $13^{\text {th }}-14^{\text {th }}$ centuries, followed by Spanish in the $16^{\text {th }}$ and $17^{\text {th }}$ centuries. The input of English in $20^{\text {th }}$-century Italian has been comparatively stronger.

2 De Mauro, Mancini (2003: viii) pointed out: “All'analisi l'inglese si rivela non solo la più latinizzata e neolatinizzata lingua del mondo non neolatino, ma in molti casi è più attivamente neolatina di lingue geneticamente neolatine nello sviluppare con i nuovi derivati il lascito della lingua di Roma." [Analyzing it, English appears to be not only the most Latinized and Neolatinized language in a non-Neolatin world, but in many cases it is actively more Neolatin than genetically Neolatin languages in the formation of new derivatives from the heritage of the language of Rome. - Transl. by VP].

3 The etymon of manager in English is ultimately from Italian maneggiare (OED). Manager was borrowed in Italian in 1895 and since then its use and productivity in compounds has steadily grown, in spite of the availability of various Italian equivalents for this job title (see Andreani, Pulcini 2016).
} 
of this word. According to Iacobini (2015: 1661), in Italian "Latin plays a dual role, constituting both the source of the native lexicon and the main source of loanwords and calques, which were absorbed into Italian in the modern age from Latin texts as well as through the mediation of other languages (mainly French and English)."

Given these premises, it follows that the influence of classical languages has contributed to the formation of a large stock of lexical items across unrelated European languages (Germanic, Romance, Slavic, etc.) displaying similar form and meaning. Moreover, in late modern times (from the mid- $18^{\text {th }}$ century), the creation and spread of neo-classical terminology was primarily conducted by major European languages, namely French and English, especially when cultural contacts and exchanges became stable and intense. Such historical affinity and shared cultural and linguistic background have been the object of inquiry in some scholarly traditions, especially among German linguists (Wexler 1969; Braun 1989).

In this paper, the lexical category of "internationalisms" will be investigated in the light of language contact and borrowing, examining in particular the vocabulary shared by English and Italian, whether of international nature or as the outcome of lexical borrowing. We argue that, even when the English provenance of a loanword can be ascertained on historical grounds, the neo-classical composition of "international words" blurs and hides the origin of the terms to such an extent that they are immediately integrated into and perceived as part of the receiving language. This makes it difficult to clearly separate internationalisms from loanwords and brings to the fore the primary role of form as a crucial component for the definition of Anglicism, especially in Latin-based languages like Italian. This issue is crucial to the establishment of loanword typology and to lexicographic work. Examples from Italian dictionaries will show that there is some inconsistency regarding the labelling of many such lexical items. Finally, we will try to establish whether some selected terms can be classified as internationalisms rather than Anglicisms.

\section{Definition of internationalism}

More than an actual lexical type, according to Petralli (1992) the term "internationalism" denotes a number of different lexemes existing in different languages which, in form and meaning, can be referred to a common "(inter)lexeme" or lexical source. To put it more simply, "an internationalism is commonly defined as a word attested in a number of unrelated languages or language families, sharing a similar orthographic or phonetic shape and a partial or identical semantic field; most often, 'internationalisms' are of Greek or Latin origin" (Wexler 1969: 77). Scholarly attention addressed to international vocabulary has limited the status of "internationalism" to items that are attested in two, three or more language families. Haugen (1950) indicates Western Europe as the geographical expanse for words having similar spelling and meaning, though widely different pronunciation. Wexler (1969) provides the case of the English term electricity as an example of an international word, shared by a broad range of languages, among which he quotes Belarusian élektryčnasc, 
Russian élektričestvo, Polish elektryczność, to which we may add Spanish electri-

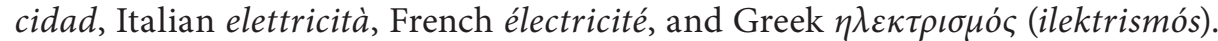
This term belongs to a subclass of internationalisms identified by Wexler (1969: 89) as "unmarked" or "denationalized", with respect to a particular national origin, and borrowed across a wide range of languages "without expressing any historical or contemporary ethno-cultural or ideological identification with a specific language or speech community". This is only one example from a massive store or scientific and technical terminology created and standardized by international bodies to disseminate knowledge and define concepts and objects unambiguously. According to Wexler (1969: 90), these internationalisms "may ultimately cease to call attention to their non-native origin in the host language; native speakers are no longer aware of the non-native origin of the form or of its cross-linguistic attestation. We may consider such forms as nationalized shared vocabulary". ${ }^{4}$

Although other languages can act as international vehicles, ${ }^{5}$ Latin represents the main shared component for such common ground across European languages: Latin was, in fact, the lingua franca of scholarly knowledge and learning from the Middle Ages to the Renaissance, then replaced by French in the following centuries $\left(17^{\text {th }}-20^{\text {th }}\right)$ up to the mid-20 ${ }^{\text {th }}$ century, when English took the upper hand as the most pervasive language of international communication in Europe and worldwide. As stated by Braun (1989: 163): "French and English have become the greatest donor languages in recent European linguistic history because both these languages have integrated and activated the Latin vocabulary to a relatively great extent".

Another subclass of internationalisms described by Wexler (1969: 86) is "vocabulary which is marked negatively with regard to national origin", by which he means new vocabulary of Latin and Greek origin acquired by a language to replace or use instead of already existing "undesirable items". Neo-classical terms may be felt as more suitable than other types of borrowing because of their international valency or for the purist desire to protect the language from neighbouring influences. Wexler gives the example of the Czech language, experiencing periods of opposition against foreign influence, especially from German, which opted for the international neologism telefon instead of the German Fernsprecher. In these cases, motivation plays a crucial role in language matters, since preferences may be favoured or dictated by political convergence or divergence in specific historical periods.

Finally, a third subclass of neo-classical vocabulary is "marked positively for national origin" (Wexler 1969: 83). In these cases, the recipient language consciously and willingly borrows from a particular donor language in order to establish an ethnocultural, political and ideological bond and identification with it. Wexler quotes the influence of classical Arabic in Islamic languages as a sign of esteem and affiliation to Muslim culture, and the influence of Russianisms in the Soviet Union to all other Soviet languages, also involving the extension of the Cyrillic alphabet. Here again

4 A rich body of literature on internationisms is available in German: for instance, Braun et al. (1990) and Munske, Kirkness (1996).

5 See footnote 6. 
motivation plays a decisive role in the acceptance or rejection of non-domestic vocabulary. We may apply this analytical framework to the success of English in Western European languages in the second half of the $20^{\text {th }}$ century, when English became the major donor of vocabulary because of its political, economic and cultural prestige after the historical divide of World War II (Pulcini forthcoming). Yet, speech communities may react differently to the assimilation of Anglicisms. If we compare the terminology of information technology in Italian, French and Spanish, for example, we may notice that Italian favours direct Anglicisms (e.g. computer, tablet, desktop), whereas French and Spanish prefer to opt for domestic substitutes or adaptations (Fr ordinateur, tablette, bureau; Sp ordenador, tableta, escritorio). In these cases, we talk about English-induced lexical borrowing (Anglicisms) and not about internationalisms, because the source language is clearly identified.

In sum, the prerequisites that make a word/term international are met in the first two cases, i.e. to be "unmarked" or "denationalized" with respect to a particular national origin, and to be "marked negatively with regard to national origin". In other words, internationalisms represent a shared lexical asset for a number of languages, unmarked for any specific cultural or ideological tie with a single, recognizable source. In addition, further qualifying conditions are formal similarity (thus excluding loan translations) and semantic equivalence (thus excluding false friends), geographical spread across language boundaries and classical etymology. ${ }^{6}$

\section{Anglicisms or internationalisms?}

The difficulty posed by the identification of internationalisms as opposed to borrowings from identifiable national sources was seriously considered by the lexicographer Manfred Görlach when he planned the Dictionary of European Anglicisms (Görlach 2001). His decision was to exclude internationalisms to comply, first of all, with his definition of Anglicism, i.e. "a word or idiom that is recognizably English in its form (spelling, pronunciation, morphology) or at least one of the three [...]", whereas "most of the neo-Greek/Latin words are truly international, carrying in them no trace of the nation that coined them - unless we have extralinguistic evidence to go by" (Görlach 2003: 65). Classical etymology alone would not be enough as a criterion for exclusion. In fact, if an item displayed some Englishness in its form, then it would be admitted to the dictionary, as was the case of Italian ace (the tennis term) because of its English pronunciation [eIs], normally heard in Italian, which gives this word an Anglicism status, despite its classical etymology (Old French as, classical Latin as < coin < Italian asso). The same applies to the Latinate word deodorant (from the present participle of the Latin verb *deodōrāre), first excluded from the dictionary but later readmitted for its clear English provenance in some of the languages featuring in this dictionary.

6 Not a decisive one, however. Wexler (1969), in fact, mentions examples of internationalisms triggered by French, German, Arabic and Russian sources, irrespective of Latin/Greek roots. 
Görlach's decision to exclude internationalisms from the Dictionary of European Anglicisms was also motivated by the need to keep the number of entries to a manageable size, in order to produce a volume in a relatively short time and provide a preliminary "snapshot" of the impact of English on sixteen European languages up to the early 199os. However, if we look at other national dictionaries of Anglicisms (Pulcini et al. 2012) and also at dictionaries of national languages, we find that more open criteria of inclusion are applied and a larger number of items are recorded as Anglicisms, especially as far as adapted forms and calques are concerned.

As pointed out above, historical information on the coinage of a term may be available to confirm its origin. For example, agnostic (noun and adjective) is labelled as "ingl." (inglese, 'English') by the Grande Dizionario dell'Uso (GDU). This term was coined by the English biologist Thomas Henry Huxley in 1869 and borrowed in the Italian language in 1870 with the meaning of 'A person who believes that nothing is known or can be known of immaterial things, especially of the existence or nature of God' $(O E D)$. We find this term in many different languages in their respective forms: agnostico (Italian), agnostique (French), agnóstico (Spanish and Portuguese), Agnostiker n. agnostizistisch adj. (German), agnostyczny (Polish), etc. Indeed, very few Italian speakers would be aware of the historical origin of this word, as no trace of English is detectable either in its pronunciation (adapted to the Italian pronunciation [an'nostiko]), spelling or morphology. This is a case in which It agnostico may be labelled as an Anglicism only on historical grounds.

Extralinguistic evidence like historical events, inventions, spread of cultural products and the like may be weak signals of the genetic descent of a particular word or term. For example, the word morphology (from Greek $\mu о \rho \phi \eta \dot{\eta}<$ form, and $-\lambda$ oyi $\alpha<$ the name of science) was coined in 1817 by the poet and dramatist Johann Wolfgang Goethe, but the German origin of this term was forgotten when it was taken over into English in 1830 and then integrated into many different languages and used in different disciplines (Görlach 2003: 66).

Moreover, inventions may be the result of international teams of scientists and a new object or concept - and its denomination - may emerge from joint international efforts. An emblematic example is the word telephone. It is common to find in encyclopaedias that this word was introduced by the American scientist Graham Bell, who first patented this invention in 1876 . Bell, however, was not the only scientist researching into the electrical transmission of speech, and in fact he managed to file the patent of the telephone just a few hours before his rival scientist (Elisha Gray) could do it, raising a controversy over the ownership of the most valuable patent in history. In fact, earlier attempts to develop an instrument capable of transmitting sound had been made simultaneously by French, Italian and German inventors. The German scientist Johann Philipp Reis, in turn, claimed the discovery of the transmitting device of the telephone, because, according to Reiss himself, Bell's device was only capable of receiving sound. By contrast, Italian students are taught that the inventor of the telephone was the Italian scientist Antonio Meucci who, already in 1854 had built a prototype of the telephone; in 1871 he patented a discovery named telettrofono for distance communication. Meucci did not have the money 
to file a standard patent for his invention and offered the project to a company in New York. Graham Bell seized the opportunity, patented the project and obtained the international recognition for this groundbreaking invention. Meucci started a legal action against Bell to claim his rights. Only a few years later the Supreme Court upheld Meucci's appeal (but it was too late because in the meantime his patent had expired) and finally in 2002 the US Congress recognized Meucci's contribution to the invention of the telephone. These historical facts prove that extralinguistic evidence may indeed stand on shaky grounds or be influenced by multiple perspectives. Moreover, even the formal composition of the word telephone may further rule out its English or Germanic provenance: the primary etymon is the initial combining form tele- which derives from Greek $\tau \eta \lambda \varepsilon^{-}$, meaning 'afar, far off', and the final element is the final combining form -phone (from Greek $\varphi \omega v \eta$ ' voice, sound'). To conclude, neither historical facts nor its formal composition may provide sufficient evidence to consider telephone an Anglicism as far as the Italian language is concerned.

Telephone belongs to the type of "non-English" compounds in English (however contradictory this phrasing may sound), discussed by Bauer as an unusual separate category, which he terms "neo-classical compounds", i.e. "words formed in the modern European languages from elements of the classical languages, in such a way that there is no native root involved" (Bauer 1988: 248), such as the words bio.metry, bio.logy, geo.logy and geo.metry. From the perspective of Latin-based language speakers, the neo-classical etymology of words immediately triggers familiarity. To these speakers, it may seem paradoxical that many words classified by dictionaries as Anglicisms like autofocus and multimedia, do not contain a single English element. On the other hand, the Italian pronunciation of multimedia varies between [multi'medja] and ['m $\Lambda$ lti mi:dia] depending on the speakers' desire to conform to an Italian or to an English model. In short, Italians perceive the association of multimedia with other English words like mass media, new media, media center, etc.

Beside neo-classical compounds formed in modern times (hence, neo-classical), English has boosted other forms of compound coinages which involve the combination of a classical combining form with an English root (e.g. videogame), which is formally another type of compounding widespread in many European languages. In a previous study on neo-classical combining forms, Pulcini and Milani (2017) analyzed nineteen items (in frequency order: multi-video-hydro-micro-auto-telebio-mega-photo- bi-mini-porno-cyber-eco-euro-geo-mono- ortho-techno-) which are quite productive both in English and in Italian in word formation, especially in the fields of information technology and the Internet. ${ }^{7}$ The combination of a neoclassical combining form and an English word are defined as Anglo-Latinisms, as mega+store, eco+system and tele+marketing. Their present-day productivity has also developed new semantic associations, like tele- (originally from Greek tele- 'afar, far off') as the abbreviation of telephone (boosting other compounds like telemarketing) or television (boosting other compounds like teleplay and teleshopping). As far

Truly English combining forms/affixes listed in the Italian dictionary Zingarelli are only three: over-, up- and under- 
as the perception of the formal identity of these compounds, Pulcini and Milani (2017: 178) argue that these combining forms "possess a domestic appearance to Italian native speakers so that words like megastore could be classified as a hybrid loanword, containing the Italian element mega- and the English root store, if all the other cultural and social components involved in the borrowing process did not lead us to consider the word megastore as an English import word or Anglicism". This study also confirmed that the number of Anglicisms containing these combining forms is relatively small, because in Italian Latin and Greek elements are integrated into the language and composition with Italian words is far more productive than composition with English elements.

\section{Anglicisms and internationalisms in Italian}

To substantiate the argumentation conducted so far, in this section some quantitative and qualitative data on lexical items having a classical form and recorded as Anglicisms in the GDU will be discussed, comparing data with other Italian general dictionaries, i.e. Zingarelli and Devoto-Oli. The GDU is one of the most authoritative dictionaries of Italian, with a wordlist of about 270,000 words. It was published in six volumes in 1999 (this edition is known as the GRADIT) and the second update was issued 2007 in a CD-ROM version, referred to as the GDU. Zingarelli and Devoto-Oli are medium-size college dictionaries, each containing about 150,000 entries.

The GDU has a high number of usage labels, guiding users to distinguish between lemmas that are fundamental ( $\mathrm{FO}=$ fondamentale), common ( $\mathrm{CO}=$ comune), highfrequency $(\widehat{A U}=$ alto uso $)$, high availability $(\widehat{A D}=$ alta disponibilita $)$ or low-frequency $(\mathrm{BU})=$ basso uso $)$ and several others. Lemmas of foreign origin are marked as exoticisms (ES) esotismo). The label TS indicates technical and specialist terminology and is accompanied by a specific field label (e.g. sport, biology, fashion, etc.). Using the CD-ROM version it is possible to conduct advanced searches with multiple labels, refining the query to specific interest entries. Selecting English as the language of origin ("ingl.") in the search window, both non-adapted and adapted Anglicisms can be retrieved (e.g. both metrosexual and metrosessuale). On the other hand, selecting both English as the language of origin and the label (ES), only non-adapted Anglicisms are retrieved. The total number of entries having English origin in the GDU amounts to 8,196, of which 5,850 are labelled as ES and therefore have an English form. ${ }^{8}$ The adapted lemmas are thus 2,346 .

In order to extract a manageable number of lemmas for the present analysis, only the entries labelled as $\mathrm{FO}$ (fundamental), $\triangle \mathrm{AU}$ (high availability), $\triangle \mathrm{AD}$ (high frequency) and CO (common), were selected, excluding the lemmas marked as ES) (unadapted

8 All the foreign words contained in the GDU are also recorded in a separate dictionary (De Mauro, Mancini 2003). 
Anglicisms) and TS (the huge number of specialized vocabulary), reaching 376 headwords. We further slimmed down the list excluding:

a) Ethnonyms, e.g. It afgano < En afghan < Pashto afğhānī; It cornico < En Cornish (from Cornwall)

b) Latinisms (aquarium, bonus, forum): these are cases of semantic loans, when the already existing word in the recipient language acquires a new meaning from English, e.g. 'an Internet discussion forum'

c) onomatopoeias (bla bla, ping-pong)

d) brandnames (clacson, moviola)

e) eponyms (It lillipuziano < En Lilliputian, It Oscar < En Oscar)

f) exotic terms mediated by English (It opossum $<$ En opossum $<$ Algonquian äpassūm, It risciò $<$ En rickshaw < Jap jinrikisha)

g) calques, e.g. It nonsenso < En nonsense, It banconota $<$ En banknote, It ciclostile $<$ En cyclostyle

h) adaptations from English etymons, e.g. It dribblare < En dribbling, It folclore < En folklore, It bistecca $<$ En beef-steak

The final list contains 33 classical-looking items, derived and adapted from English, according to the GDU, which are shown in Table 1. Column 1 contains the Italian entry word from the GDU dictionary, column 2 the English source term according to the GDU dictionary, column 3 the etymology of the English source term taken from the $O E D$, columns 4 and 5 the etymologies respectively indicated by the two general dictionaries (Zingarelli and Devoto-Oli).

Before we proceed to the analysis of the data, it is important to briefly discuss the terms "origin", "etymon" and "etymology". A dictionary normally indicates the provenance of the entry word, which may be within the language itself, like En aerobics n. from En aerobic adj. In turn, the etymon indicates the historical origin of the word; in the case of En aerobic, its etymons are Fr aerobie + -ic suffix. This information may suffice to trace the etymology of En aerobics, i.e. the historical steps made by a word to assume the current form, which in this case is pretty simple. A historical dictionary is usually very detailed as far as origins and etymologies are concerned, like the OED for English. "Remote" etymology traces the word's history back in time, most often to Latin and Greek, but, for English, also Old or Middle French and Germanic, less frequently Gaelic, Norse or Gaulish. In many cases, the words' historical routes of transmission are complex and multiple, or even unknown or simply reconstructed. By internal or "immediate" etymology is meant the development of form and meaning within the language, such as the more recent route of transmission (source of borrowing) of a word in a language. In "abridged" or "specialized" dictionaries, etymological information may be limited to the essential. In loanword lexicography (van der Sijs 1996), for example, the "immediate" etymology, that is the most recent source of the borrowed item, may be deemed more important than the remote one.

Apart from formal changes, also variation in pronunciation and meaning that words have developed throughout their lifetime from the root etymons to modern 
uses are important information for tracing the historical profile of words. For example, It armonica (from En harmonica, i.e. mouth-organ) was coined on Lat harmonicus 'musical'. The names of modern discoveries, inventions or activities are often loosely linked to the meaning of their formal constituents, as in the term aerobics discussed above, which exploits the ancient Greek combining form $\alpha \dot{\varepsilon} \rho o$ (referring to air) and Greek/Latin bio- (referring to life) to name this new modern type of physical exercise. The 'the father of aerobics' was the American doctor of medicine Kenneth H. Cooper, who studied the beneficial effects of healthy lifestyle and fitness on cardiovascular diseases and popularized this particular type of workout in his book Aerobics published in 1968. This is the reason why aerobica is recorded as an Anglo-American borrowing by the GDU (but not by Zingarelli and Devoto-Oli).

\section{Discussion}

The data presented in Table 1 will allow us to compare the lexical profile of the selected items on the basis of the etymological information recorded by the OED for English and by the GDU, Zingarelli and Devoto-Oli. Far from questioning the reliability of this information, the intent of this comparison is to highlight the multiple and complex transmission routes that words have taken in time and the difficulty to account for it for lexicographic purposes. To start with, none of the 33 lexical items shows any sign of Englishness to a native speaker of Italian, either in origin, structure or pronunciation. In fact, even if their transmission from English was to be ascertained beyond any doubt, the etymologies of the English mediation terms are classical (Latin/Greek) or Romance (French), as shown in column 4. Most sources of English words are straight from Latin (e.g. En crucial < Lat crux, -cis; En alchemic < Lat alchimicus), followed by French (e.g. En celluloid < Fr cellulose + oid; En pudding < Fr bodeyn; En tourism $<$ Fr tour $+i s m)$. Several etymons are from either or from both (e.g. En consequential $<$ Lat consequential $<$ consequence $+-a l<$ Fr consequence). Some $19^{\text {th }}$-century neoclassical coinages were first attested in German and then borrowed by English, like Absolutist (also attested in Fr absolutiste from Lat absolūtus). ${ }^{9}$

\subsection{Anglicisms}

The three Italian dictionaries considered in this study agree on the Anglo provenance of the following items: armonica, assolutista, automazione, cruciale, deterrente, deterrenza, idrante, linoleum, mascara, pandemonio, tecnicalità, traslitterazione. We will briefly provide some essential information in support of this position, when available, drawing on other sources (Rando 1987; Enciclopedia Treccani).

9 In the $18^{\text {th }}$ century the most frequent sources of loanwords were French (33\%) and Latin (30\%); in the $19^{\text {th }}$ century Latin (40.5\%), German $(18 \%)$ and French $(15.5 \%)$; in the $20^{\text {th }}$ century Latin (20\%) and French (16.5\%) (Minkova, Stockwell 2009: 53). 


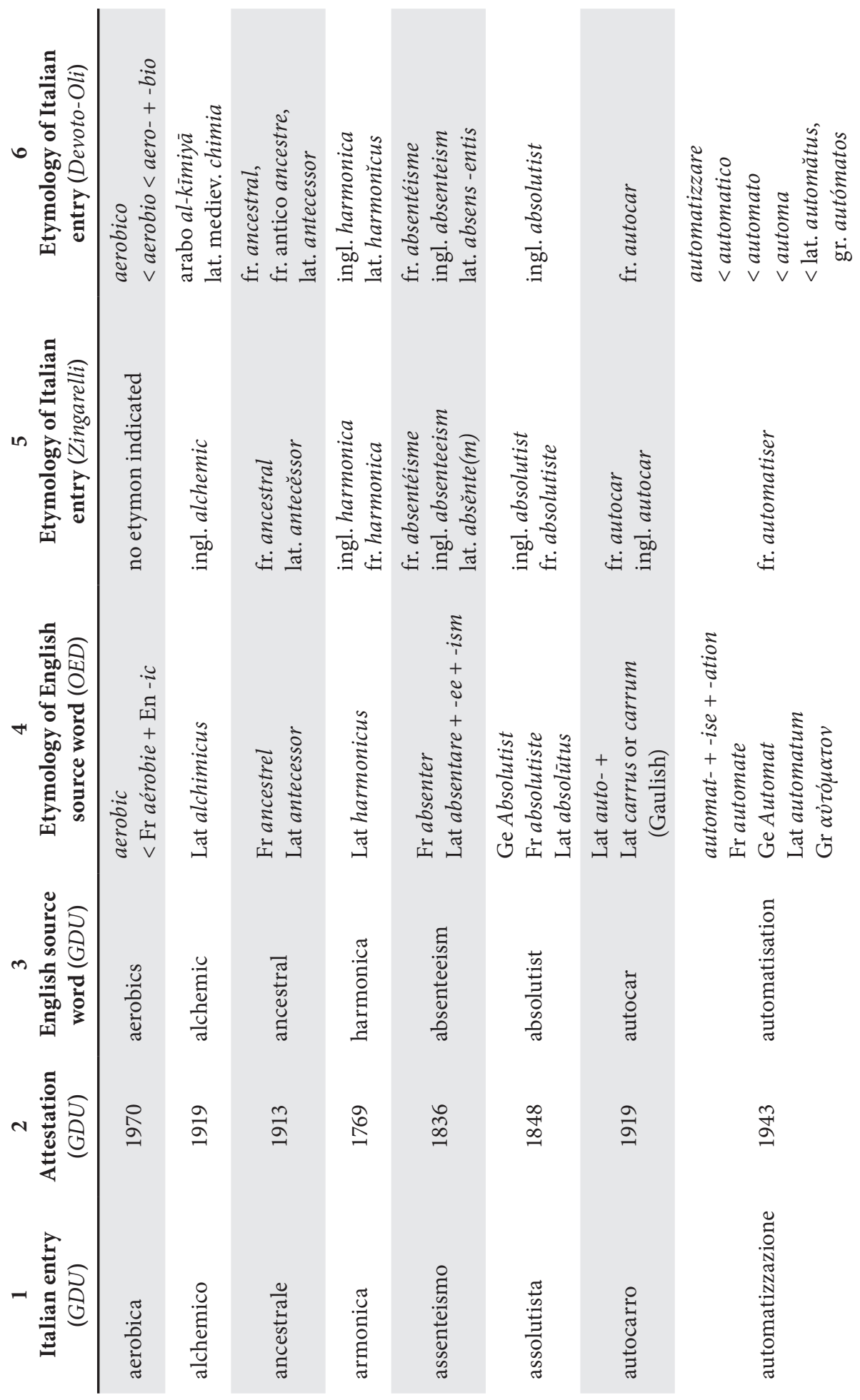




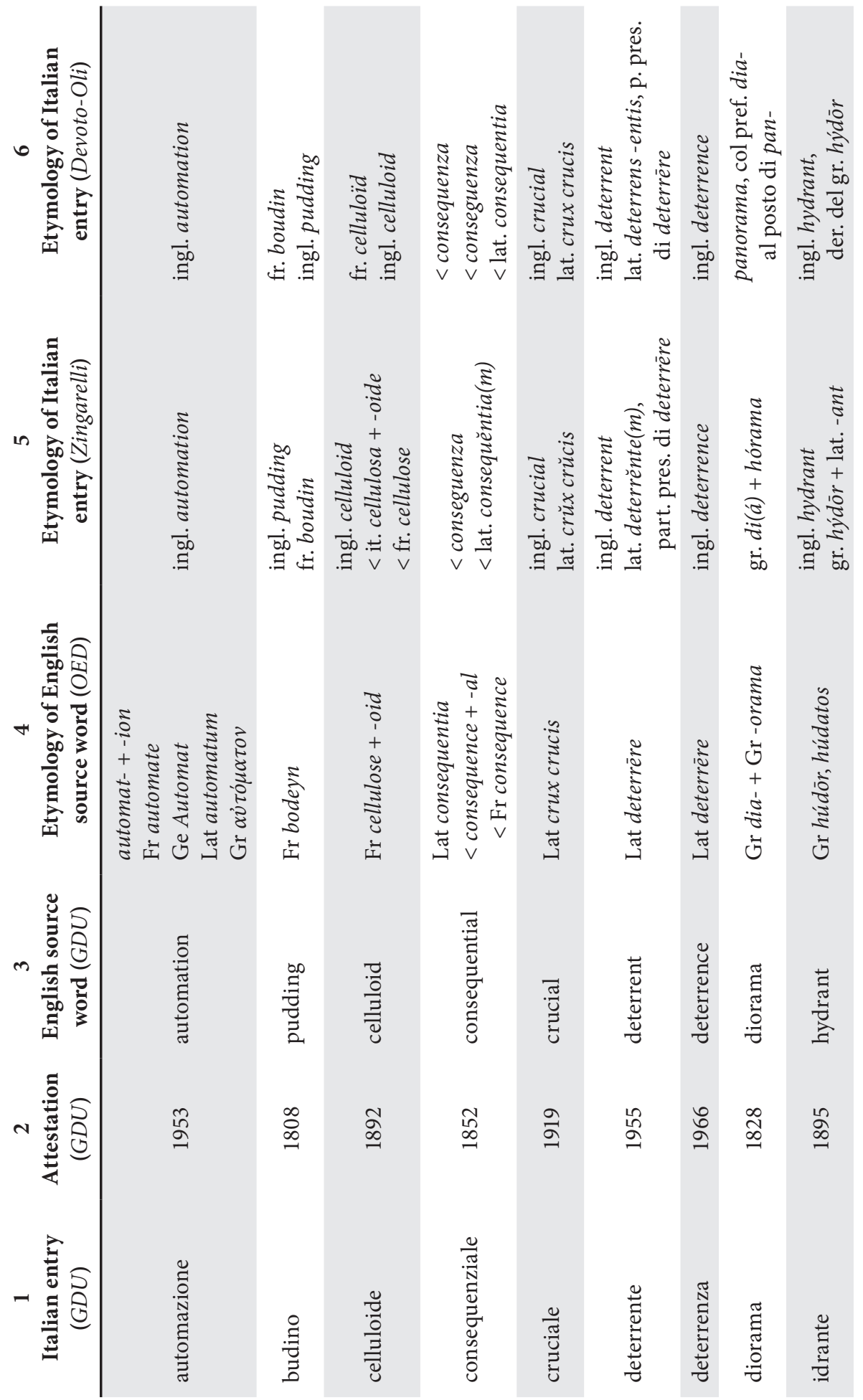




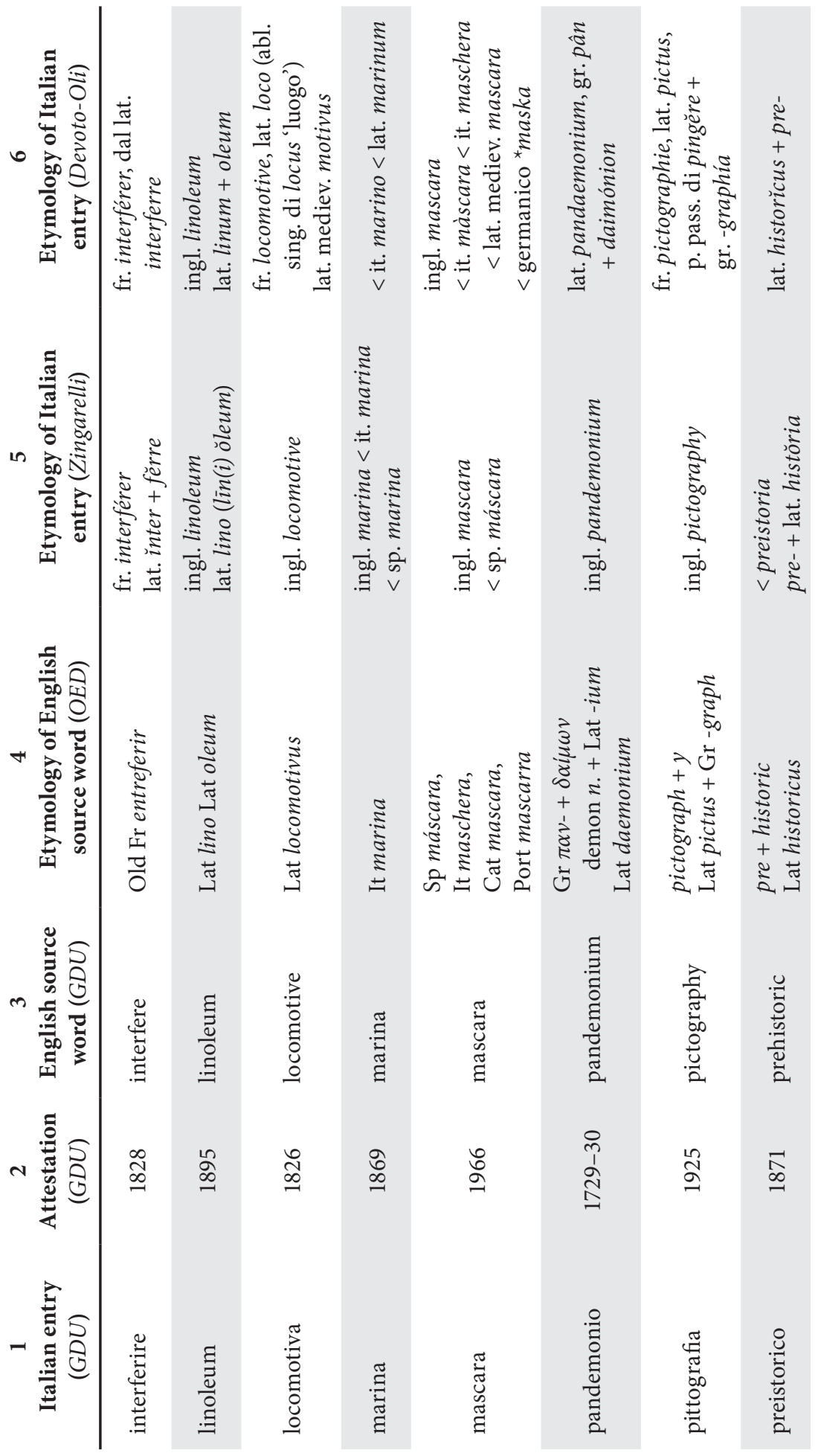




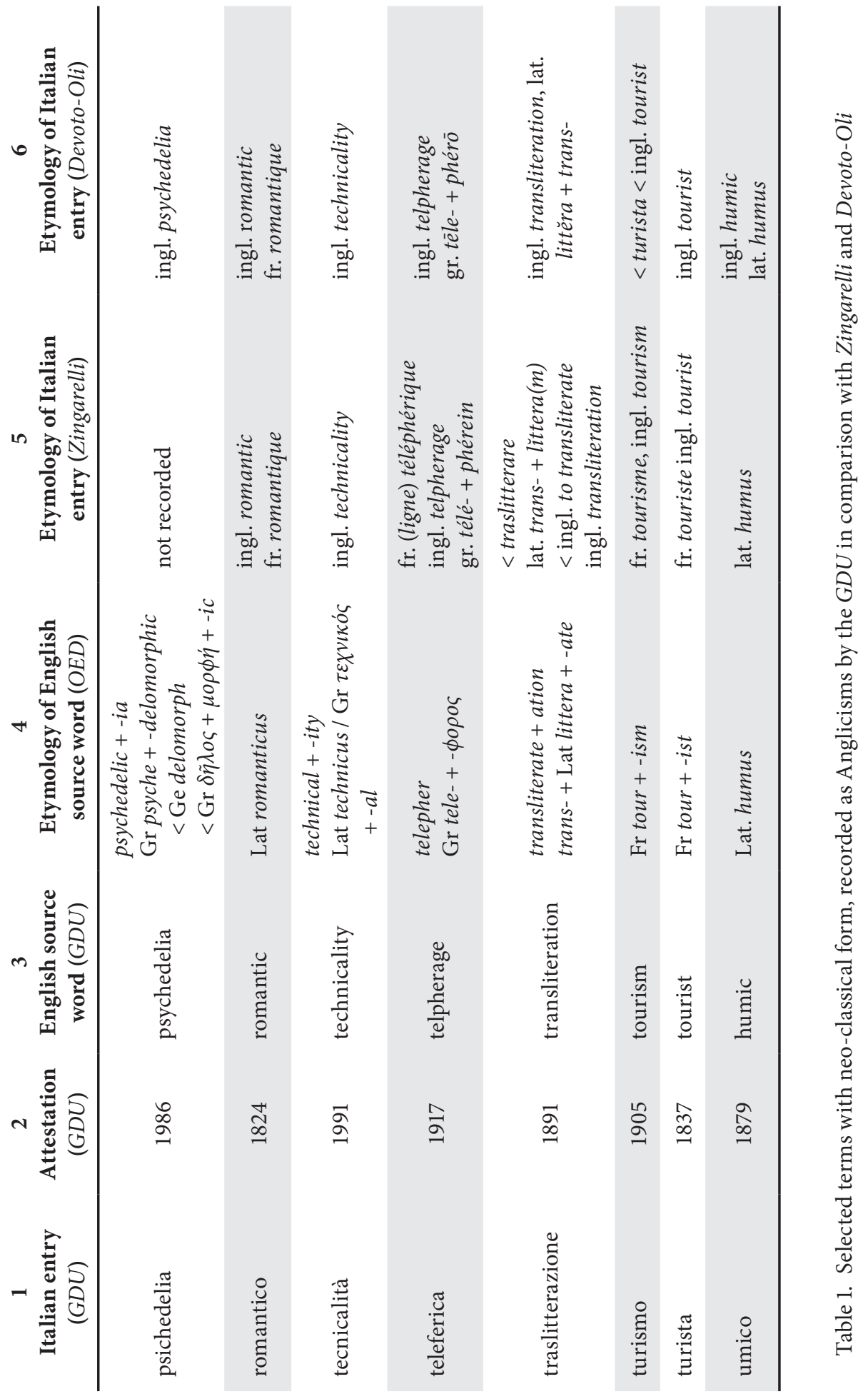


Armonica. Encyclopedic information seems to confirm that armonica is a musical instrument of English origin ( $18^{\text {th }}$ century), invented by Benjamin Franklin in 1761 , which later gave the name to other types of musical instruments.

Assolutista. The political term assolutista, i.e. 'A supporter or advocate of absolute government' $(O E D)$, also borrowed from French (according to Zingarelli), does not seem to be attached to any nation in particular, although it was theorized by many European thinkers.

Automazione (from En automation), also attested in Rando's dictionary (1987), was created by D.S. Harder, vice-president of the Ford car company in 1947.

Cruciale (adjective from En crucial), also attested by Rando (1987) as used in Francis Bacon's Novum Organum, also through the French word crucial, is confirmed as an English loan by the three dictionaries, beside its Latin etymology.

Deterrente, deterrenza. These nouns are respectively attested as from En deterrent and deterrence, beside their Latin etymology from the verb deterrēre 'to scare away'; they are said to have been introduced in political discourse after World War II with reference to strategic weapons, especially nuclear bombs.

Idrante (from En hydrant, 'An apparatus for drawing water directly from a main, esp. in a street', $O E D$ ) does not apparently have any historical connection with the British or American society.

Linoleum. This Latin-looking term is said to have been invented by the English Frederick Walton in 1863 and introduced in Italian in 1895 as a homograph, although its pronunciation is adapted to Italian. Originally a trademark, linoleum became a generic term in $1878 .^{10}$

Mascara. The etymology of mascara appears to be particularly intriguing: the three Italian dictionaries date the borrowing of this word to 1966 with the meaning of 'A cosmetic preparation for darkening, lengthening, and thickening the eyelashes' $(O E D)$; historically, mascara is a Spanish loan in the English language with multiple etymons in Spanish máscara, Italian maschera, Catalan mascara, Portuguese mascarra, etc. Due to its homographic status in both languages (also the Italian pronunciation is quite similar to the English one), this word is hardly perceived an as Anglicism.

Pandemonio (from En pandemonium) was created by John Milton in his poem Paradise Lost to name the capital of hell; hence its English provenance attested by two dictionaries with the figurative sense of 'noisy, chaotic place or situation'.

Tecnicalità is recorded as a loan from En technicality by the reference dictionaries for no particular historical motivation.

Traslitterazione is recorded as a loan from En transliteration by two out of three dictionaries, with the meaning of 'rendering of the letters or characters of one alphabet in those of another' (OED) as a linguistic activity and no plausible connection to English or American society or events.

Umico is given as an Anglicism from En humic by two sources out of three, whereas Zingarelli quotes only the Latin etymology (humus 'ground').

10 Linoleum is said to be one of the first trademarks to become a generic term in 1878 , as explained in a volume dedicated to this flooring product, Linoleum, by Jane Powell (2003). 
In conclusion, the lexicographic evidence supporting the status of English loanword for the entries illustrated in this section seems to be based mostly on historical grounds, i.e. as the invention or phenomenon introduced for the first time in the British or American worlds or culturally linked to them. Such historical evidence appears to be blurred in time, and sometimes not even retrievable from encyclopedic sources. We may safely state that no "ethno-cultural, political and ideological bond" with the Anglo identity or heritage (discussed above with reference to Wexler's approach [1969]) is detectable by the average Italian speaker.

\subsection{Multiple sources}

The examples illustrated in this section are recorded by the reference dictionaries as deriving from multiple sources, i.e. either French or English, or both. This phenomenon is not at all unusual; on the contrary, simultaneous borrowing, or borrowing from one of these languages through the mediation of the other was quite frequent in the $18^{\text {th }}$ and $19^{\text {th }}$ centuries.

Assenteismo. The origin of the It word assenteismo is registered as from $\mathrm{Fr}$ absentéisme and En absenteeism (beside the Latin etymon absěnte $(m)$ ), although Zingarelli explains in its first meaning given for this word that this practice was widespread among $19^{\text {th }}$ century English landowners who lived away from their properties and neglected their interests (the second meaning is the semantic extension of 'persistent habit of absenting oneself (from work, church, school, etc.)' (OED).

Multiple provenance from English and French is also recorded for the words listed below.

Autocarro (Fr autocar, En autocar)

Budino (En pudding, Fr boudin). The meaning of puddingll may refer to both a sweet dish made of flour and milk and a type of sausage or mixed meat dish, with an endless variety of recipes. Italian budino is used only for the meaning of a sweet dish.

Celluloide (Fr celluloid, En celluloid)

Locomotiva (En locomotive, Fr locomotive)

Pittografia (En pictography, Fr pictographie)

Romantico. Italians may be quite surprised to learn that the word romantico derives from $17^{\text {th }}$-century En romantic, meaning 'picturesque, fictional', in turn from Fr romantique (< Fr roman 'novel'), having acquired the main meaning of 'Designating, relating to, or characteristic of a movement or style during the late $18^{\text {th }}$ and $19^{\text {th }}$ centuries in Europe marked by an emphasis on feeling, individuality, and passion [...]' (OED).

Turismo and turista originated from En tourism and tourist, in turn from Fr tour.

11 The etymology of En pudding is given as from Anglo-Norman bodeyn, bodin (sausage), in the plural (bodeyns) with reference to animal intestines. See the OED entry for pudding for further etymology, which is uncertain and controversial. 


\subsection{Other sources}

Marina. The status as Anglicism of It marina poses serious doubts, as its origin and etymon in English are straight from the Italian language. The oldest meaning of both It and En marina (from Lat marinus 'belonging to the sea') is 'That part of a coastal town, esp. a resort, which adjoins the sea', which, according to the OED, is now rare in English. The more recent $20^{\text {th }}$-century meaning, which is said to have developed in US English and then "reborrowed" by Italian is 'A dock, harbour, or basin in which yachts and other small craft are moored'. Zingarelli records this meaning as from En through It and Sp Devoto-Oli does not mention any En origin at all.

Interferire. Another doubtful case. Only the GDU records this word as an English borrowing, whereas the other two dictionaries mention a possible influence of Fr interférer (etymology: Lat interferre). In this case, disagreement in the lexicographic sources may lead to the conclusion that there is a multiple origin for this verb, both from French and English, as is the case of many borrowings discussed in the previous section.

Teleferica. Another doubtful case. The It term teleferica is recorded by the GDU as a borrowing from En telpherage. Although there is agreement on this in the three dictionaries, together with a possible multiple borrowing from Fr (ligne) téléphérique, the formal difference between the It and En terms raises legitimate doubts regarding the actual path of transmission. First of all, the Fr term is formally more similar to the It one. Secondly, the noun telepheric is attested in the OED as a borrowing from Italian with the meaning of 'cableway' or 'cable car' 'chiefly in Italian and Spanish contexts' (first attestation in the OED in 1916). Moreover, the meaning of English telpherage appears to be attested in the late $19^{\text {th }}$ century (etymology: Gr tele- + - фo o 'Transport effected automatically by the aid of electricity; spec. a system adapted to the conveyance of minerals and other goods in vessels suspended from a cable [...]'. No quotations are present in the OED after 1888. This may lead us to hypothesize that the link between It teleferica and En telpherage is indeed very thin, both formally and semantically. Moreover, It teleferica is likely to have been borrowed later (1916) by English for the more specific meaning of 'cable car'.

\subsection{International candidates}

In this section some lexical items have been selected as candidate "international words" rather than Anglicisms. The choice of words/terms was motivated by various objective reasons, but also guided by experienced intuition. First, most terms are recorded as Anglicisms by the GDU but not by the other dictionaries. Second, these terms appear culturally neutral, monosemic, and likely to be used by many languages for similar denotative motivations. As pointed out in section 2 the prerequisites for a word/term to be considered truly international are: (a) to have classical/neoclassical etymology, (b) to be spread across language boundaries, (c) to share formal 
and semantic similarity, (d) to be unmarked for any specific cultural or ideological link with a recognizable source, (e) to represent a shared lexical asset for a number of languages. In our view, all these words could potentially satisfy these conditions. The only exception is aerobics for its origin in the US, but we deem this term international enough to verify its cross-cultural valency.

The results shown in Table 2 confirm that the "interlexeme" that encompasses these look-alike terms in the shaded columns (represented by It aerobica, alchemico, automatizzazione, diorama, and psichedelia) fully satisfy the stated prerequisites, being shared by eight European languages of three language families - Romance, Germanic and Slavic. The word preistorico is partly shared by the three language families, with the exception of Danish and Norwegian for the Germanic branch. By contrast, ancestrale and consequenziale are only shared by Romance languages and therefore do not qualify as "internationalisms". Incidentally, Polish konsekwentny ('consistent') is a false friend of English consequential.

\section{Conclusion}

For several centuries, for better and for worse, Western European societies have shared a large amount of social history, and their languages have come into direct, intimate contact through multiple paths of transmission. In modern times, these linguistic and cultural ties were strengthened by French and English, the two big languages of international communication in Europe. Acting jointly, Latin and Greek - the languages of classical civilization and heritage - which are the genetic substratum of Romance languages, have continued to offer lexical resources for the creation of academic, learned vocabulary, and technical and scientific terminologies in all European languages. These cultural and linguistic ties explain the existence of matching "international" vocabulary, which is considered by some scholars an important and useful resource not only to facilitate communication and understanding in present-day Europe, but also to identify and describe unique features of Pan-European culture (Braun 1989).

In the light of this historical background, this paper has addressed the lexical category of internationalisms and tried to clarify its relevance to the nearby area of linguistic borrowing. In fact, whereas "international words" are characteristically unmarked for a specific national origin (i.e. "denationalized" vocabulary available in a number of languages), borrowings keep traits of foreignness and remain "positively marked for national origin" or "-isms" (Anglicisms, Gallicisms, Latinisms, etc.). In our data, we identified a few cases of potential "internationalisms", namely the "interlexeme" represented by It aerobica, alchemico, automatizzazione, diorama, and psichedelia and their respective look-alike equivalents in eight European language, although these words are recorded as English borrowings by the GDU.

Because of their neo-classical composition, a problem posed by "internationalisms" in Romance languages like Italian is to distinguish English loanwords from non-loanwords, i.e. adapted Anglicisms from truly assimilated domestic words, when 

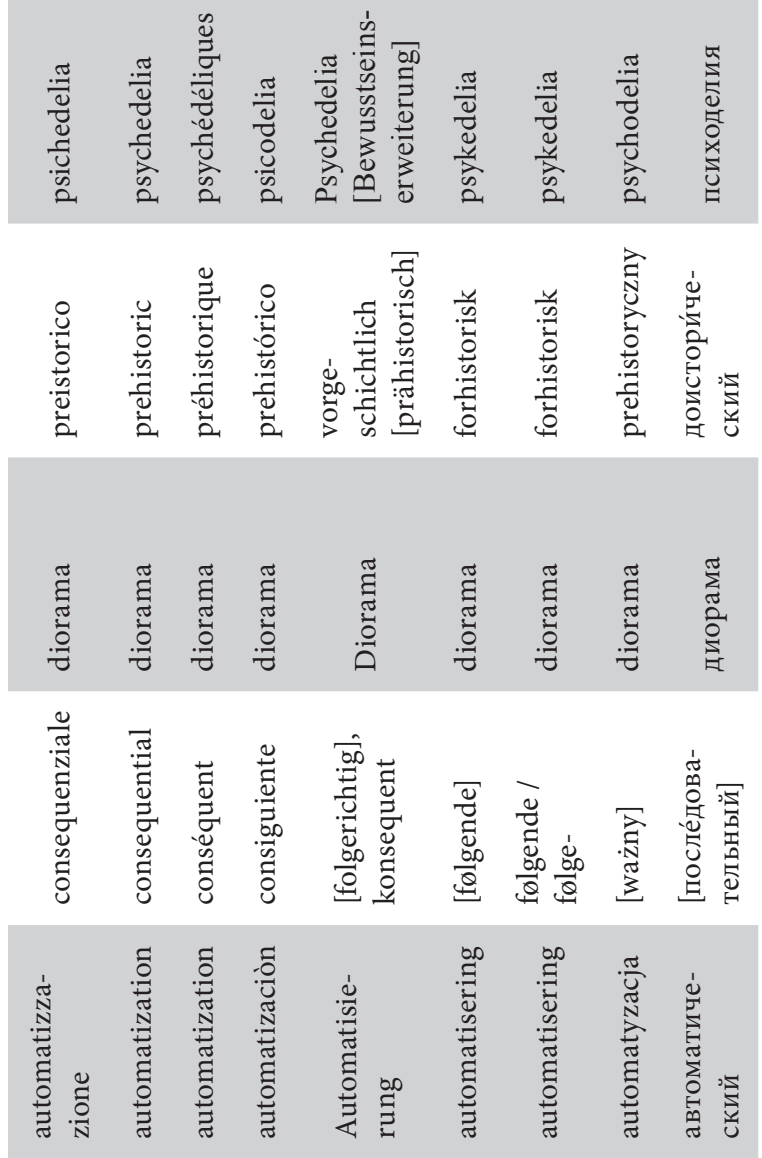

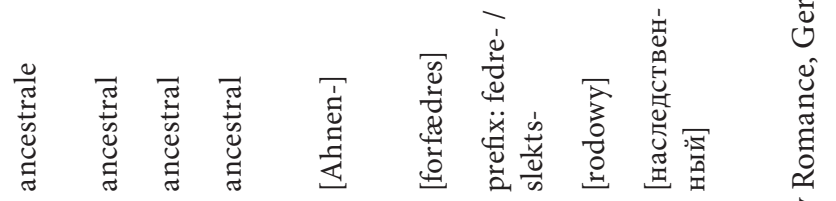

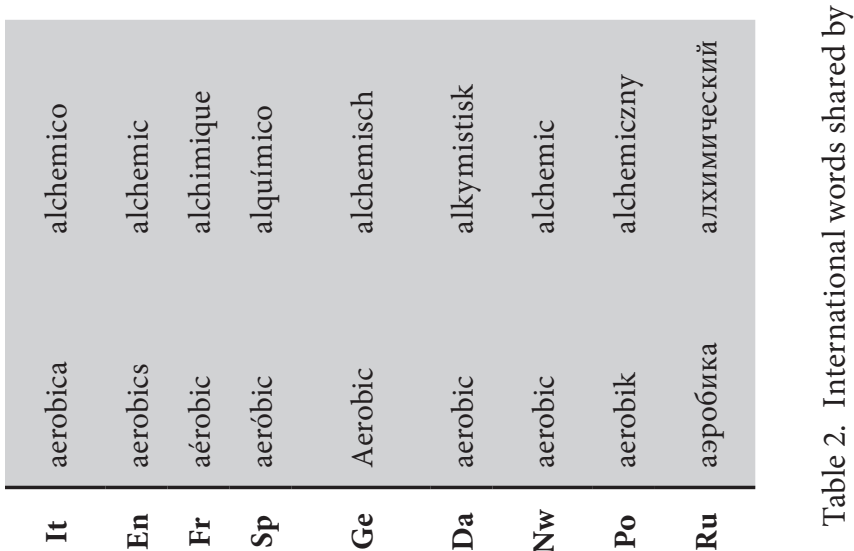


these are made up of classical/neoclassical elements. To any Italian speaker, even to expert ones, the 33 lexical items recorded as English borrowings by the GDU are indeed formally undistinguishable from Italian words. We have argued that historical evidence in support of the provenance of these terms from Anglo contexts is not strong enough, and the prototypical case of It telefono showed how controversial it may be to attribute the paternity of a neologism. Furthermore, data showed that multiple etymology is the rule rather than the exception, and information provided by dictionaries is sometimes limited or discordant. Far from denying the authoritativeness of the Italian dictionaries taken as reference sources, conflicting information proves that language contact and borrowing take multiple paths, so that it may be controversial to determine whether a word actually came separately from French, English or together from both sources, or perhaps directly from classical roots.

Intuitively, many educated Italian speakers would consider it puzzling or even unacceptable to label words like armonica, cruciale or idrante as English borrowings, whereas no doubts at all would be raised for words that are "recognizably English in form (spelling, pronunciation, morphology)". Thus, from the perspective of a Latin-based language like Italian, the distinction between foreign (-isms) and non-foreign vocabulary (domestic or international) on the basis of formal criteria and users' perceptions towards their own mother tongue seems to be more viable and convincing than language-external evidence.

\section{References}

Andreani A., Pulcini V. 2016. English job titles in Italian. The case of 'Manager' and 'Engineer'. - Lingue e Linguaggi 19: 7-21.

Bauer L. 1988. Introducing linguistic morphology. Edinburgh.

Braun P. 1989. Internationalisms: Identical vocabularies in European languages. - Coulmas F. (ed.). Language adaptation. Cambridge: 158-167.

Braun P., Schaeder B., Vollmert J. (eds.). 1990. Internationalismen. Studien zur interlingualen Lexikologie und Lexikographie. Tübingen.

Carstairs-McCarthy A. 2002. An introduction to English morphology: Words and their structure. Edinburgh.

De Mauro T., Mancini M. 2003. Parole straniere nella lingua italiana. [1 ${ }^{\text {st }}$ edition 2001]. Torino. $G D U=$ De Mauro T. (ed.). 2007. Grande dizionario italiano dell'uso. [with G.C. Lepschy, E. Sanguineti, $3^{\text {rd }}$ edition $+c d$ rom and USB drive; $1^{\text {st }}$ edition 1999]. Torino.

Devoto-Oli = Devoto G., Oli G.C., Serianni L., Dardano M. 2018. Nuovo Devoto-Oli. Il vocabolario dell'italiano contemporaneo. Firenze.

Enciclopedia Treccani. [www.treccani.it].

Görlach M. (ed.). 2001. A dictionary of European Anglicisms. Oxford.

Görlach M. 2003. English words abroad. Amsterdam, Philadelphia.

Haugen E. 1950. The analysis of linguistic borrowing. - Language 26.2: 210-231.

Hogg R., Denison D. 2006. A history of the English language. Cambridge.

Iacobini C. 2015. Foreign word-formation in Italian. - Müller P.O., Ohnheiser I., Olsen S., Reiner F. (eds.). Word-formation. An international handbook of the languages of Europe. [vol. 3]. Berlin, New York: 1660-1679. 
Minkova D., Stockwell R. 2009. English words: History and structure. [2 ${ }^{\text {nd }}$ edition]. Cambridge. Munske H.H., Kirkness A. (eds.). 1996. Eurolatien. Das griechische und lateinische Erbe in den europäischen Sprachen. Tübingen.

OED = Oxford English Dictionary. [www.oed.com].

Petralli A. 1992. Tendenze europee nel lessico italiano. Internazionalismi: problemi di metodo e nuove parole d'Europa. - Moretti B., Petrini D., Bianconi S. (eds.). Linee di tendenza dell'italiano contemporaneo. Roma: 119-134.

Plag I. 2003. Word-formation in English. Cambridge.

Powell J. 2003. Linoleum. Layton (Utah).

Pulcini V. 1997. 'Friends' and 'false friends' in the English language. - Pulcini V. (ed.). La didattica della lingua inglese. Percorsi per l'aggiornamento 1994-95. Alessandria: 149-161.

Pulcini V. 2002. Italian. - Görlach M. (ed.). English in Europe. Oxford: 151-167.

Pulcini V. 2017. Anglicisms in Italian: Moving on into the third millennium. - Boggio C., Molino A. (eds.). English in Italy: Linguistic, educational and professional challenges. Milano: 13-35.

Pulcini V. [forthcoming]. The English language and Anglo-American culture in twentiethcentury Italy. - Bonsaver G., Carlucci A., Reza M. (eds.). Italy and the USA. Cultural change through language and narrative. Oxford.

Pulcini V., Furiassi C., Rodríguez González F. 2012. The lexical influence of English on European languages: From words to phraseology. - Furiassi C., Pulcini V., Rodríguez González F. (eds.). The Anglicization of European languages. Amsterdam, Philadelphia: 1-24.

Pulcini V., Milani M. 2017. Neo-classical combining forms in English loanwords: Evidence from Italian. - ESP Across Cultures 14: 175-196.

Rando G. 1987. Dizionario degli Anglicismi nell'italiano postunitario. Firenze.

Tekavčić P. 1980. Grammatica storica dell'italiano. Bologna.

Van der Sijs N. 1996. The codification of etymological information. - Van Sterkenburg P. (ed.). A practical guide to lexicography. Amsterdam, Philadelphia: 312-321.

Wexler P. 1969. Towards a structural definition of 'internationalisms'. - Linguistics 48: 77-92. Zingarelli = Zingarelli N. 2017. loZingarelli 2018. Vocabolario della lingua italiana. Bologna. 
